medRxiv preprint doi: https://doi.org/10.1101/2021.07.29.21261196; this version posted July 31, 2021. The copyright holder for this preprint (which was not certified by peer review) is the author/funder, who has granted medRxiv a license to display the preprint in perpetuity.

It is made available under a CC-BY-NC-ND 4.0 International license.

\title{
Prospective examination of mental health in university students during the COVID-19 pandemic
}

Ru Jia ${ }^{1}$, Holly Knight ${ }^{1}$, Kieran Ayling $^{1}$, Carol Coupland ${ }^{1}$, Jessica Corner $^{2}$, Chris Denning ${ }^{3}$, Jonathan Ball ${ }^{4}$, Kirsty Bolton ${ }^{5}$, Joanne R Morling ${ }^{1}$, Grazziela Figueredo ${ }^{6}$, David Ed Morris ${ }^{7}$, Patrick Tighe $^{4}$, Armando Villalon ${ }^{7}$, Holly Blake ${ }^{8,9}$, Kavita Vedhara $^{1 *}$

${ }^{1}$ School of Medicine, University of Nottingham, University Park, Nottingham, $N G 72 R D, U K$.

${ }^{2}$ University Executive Board, University of Nottingham, Nottingham, NG7 2RD, UK.

${ }^{3}$ Biodiscovery Institute, University of Nottingham, University Park, Nottingham, NG7 2RD, $U K$.

${ }^{4}$ School of Life Sciences, The University of Nottingham, Nottingham, UK

${ }^{5}$ School of Mathematical Sciences, University of Nottingham, University Park, Nottingham, $N G 72 R D, U K$.

${ }^{6}$ School of Computer Science, University of Nottingham, Nottingham, NG8 1BB, UK.

${ }^{7}$ Bioengineering Research Group, Faculty of Engineering, University of Nottingham, University Park, Nottingham, NG7 2RD, UK.

${ }^{8}$ School of Health Sciences, University of Nottingham, QMC, Nottingham, NG7 2HA, UK.

${ }^{9}$ NIHR Nottingham Biomedical Research Centre, Nottingham, UK.

* Author to whom all correspondence should be addressed: Professor Kavita Vedhara, School of


Kavita.vedhara@nottingham.ac.uk; Tel +44 1158466931 
medRxiv preprint doi: https://doi.org/10.1101/2021.07.29.21261196; this version posted July 31, 2021. The copyright holder for this preprint

RJ: MSc [Research Assistant]

H.K: PhD [Senior Research Fellow]

KA: PhD [Senior Research Fellow]

CC: PhD [Professor of Medicine Statistics in Primary Care],

JC: PhD [Pro-Vice-Chancellor and Professor of Cancer and Supportive Care],

$\mathrm{CD}$ : PhD [Professor of Stem Cell Biology, Director of the Biodiscovery Institute],

JB: PhD [Professor of Molecular Virology],

KB: PhD [Research Fellow],

JRM: PhD [Clinical Associate Professor in Public Health],

GF: PhD [Senior Research Data Scientist],

DEM: PhD [Assistant Professor in Electronic Engineering],

PT: PhD [Associate Professor of Immunology],

AV: $\mathrm{PhD}$ [Research Fellow],

H.B: PhD [Associate Professor of Behavioural Science],

KV: PhD [Professor of Health Psychology]

\section{Declarations}

\section{Funding}

The study was funded by the Medical Research Council (Reference: MC_PC_20027,

Principal Investigator J.B.) and the Institute for Policy and Engagement at the University of

Nottingham (QR Duning Award, H.B., J.R.M., K.V.). JRM receives salary support from a

Medical Research Council Clinician Scientist Fellowship [grant number MR/P008348/1].

The sponsors had no involvement in the study design, the collection, analysis and 
medRxiv preprint doi: https://doi.org/10.1101/2021.07.29.21261196; this version posted July 31,2021 . The copyright holder for this preprint

interpretation of data, or the preparation of the article. The views expressed are those of the authors and not necessarily those of the funders.

\section{Conflicts of interest}

All authors were employees of University of Nottingham (UoN), the institution at which data were collected. J.C. sits on the Executive Board for UoN. No other conflicts of interest were declared.

\section{Ethics approval}

Ethical approval was received from the University of Nottingham Faculty of Health Sciences Research Ethics Committee (FMHS 96-0920).

\section{Consent to participate}

Informed consent was obtained from all participants for being included in the study.

\section{Consent for publication}

Not applicable.

\section{Availability of data and material}

Data will be deposited in the University of Nottingham data archive. Access to this dataset will be embargoed for a period of 12 months in order for us to complete further analysis of the dataset. After that it may be shared with the consent of the Chief Investigator.

\section{Code availability}

Not applicable.

\section{Author contributions}


medRxiv preprint doi: https://doi.org/10.1101/2021.07.29.21261196; this version posted July 31, 2021. The copyright holder for this preprint (which was not certified by peer review) is the author/funder, who has granted medRxiv a license to display the preprint in perpetuity.

It is made available under a CC-BY-NC-ND 4.0 International license.

All authors designed the study. RJ analysed the data and RJ, HK and KV wrote the first draft.

All authors provided critical revisions. All authors read and approved the submitted manuscript. 


\title{
Prospective examination of mental health in university students during the COVID-19 pandemic
}

\author{
Abstract \\ Background: The impact of changing social restrictions on the mental health of students \\ during the COVID-19 pandemic warrants exploration.
}

Aims: To prospectively examine changes to university students' mental health during the pandemic.

Methods: Students completed repeated online surveys at three time points (October 2020 (baseline), February 2021, March 2021) to explore relationships between demographic and psychological factors (loneliness and positive mood) and mental health outcomes (depression, anxiety, and stress).

Results: A total of 893 students participated. Depression and anxiety levels were higher at all timepoints than pre-pandemic normative data $(p<.001)$. Scores on all mental health measures were highest in February, with depression and anxiety remaining significantly higher in March than baseline. Female students and those with previous mental health disorders were at greatest risk of poor mental health outcomes. Lower positive mood and greater loneliness at baseline were associated with greater depression and anxiety at follow-ups. Baseline positive mood predicted improvement of depression and anxiety at follow-ups.

Conclusion: Depression and anxiety were significantly higher than pre-pandemic norms, with female students and those with previous mental health difficulties being at greatest risk.

Given these elevated rates, universities should ensure adequate support is available to meet potentially increased demand for services. 
medRxiv preprint doi: https://doi.org/10.1101/2021.07.29.21261196; this version posted July 31, 2021. The copyright holder for this preprint (which was not certified by peer review) is the author/funder, who has granted medRxiv a license to display the preprint in perpetuity.

It is made available under a CC-BY-NC-ND 4.0 International license .

Key words: covid-19, university students, mental health, loneliness, positive mood 
medRxiv preprint doi: https://doi.org/10.1101/2021.07.29.21261196; this version posted July 31, 2021. The copyright holder for this preprint (which was not certified by peer review) is the author/funder, who has granted medRxiv a license to display the preprint in perpetuity.

It is made available under a CC-BY-NC-ND 4.0 International license .

\section{Introduction}

Young adults have been shown across many studies to have been at the greatest risk of mental health difficulties. (Jia, Ayling, Chalder, Massey, Broadbent, Morling, et al., 2020; Odriozola-González et al., 2020; Shanahan et al., 2020) During the Covid-19 pandemic, university students, as a subgroup of young people whose education, as well as other aspects of life, were disrupted were reporting increased levels of anxiety, depression, stress worldwide, during the initial phase of lockdowns. (Meda et al., 2021; Odriozola-González et al., 2020) The social restriction measures, however, changed frequently due to fluctuating levels of infections and mortality, serving as additional stressors. The Office for National Statistics (ONS) data suggested that in November 2020 more than half (57\%) of the students reported slightly worsened wellbeing and mental health since starting the Autumn term, which increased to $63 \%$ in January. (ONS) Given the fluctuations in restrictions and their subsequent impact on students' lives, it is therefore important to understand not only the prevalence of mental health difficulties during the various phases of the pandemic, but also the determinants of who is at greatest risk of mental health difficulties, as well as those who remain resilient. According to stress and coping theory, we would not expect effects on mental health to be uniform but to vary according to an individual's cognitive appraisal and available psychosocial resources. (Folkman et al., 1991) Indeed, evidence from early in the pandemic has identified that female gender and prior mental health disorders were risk factors of anxiety, depression, and other mental health difficulties among both the general population (Xiong et al., 2020) and university students. (Elmer et al., 2020; Meda et al., 2021) However, these are demographic and clinical risk factors which cannot be modified. There are likely to be other psychological, potentially modifiable risk factors, that could also be important in understanding the risk of mental health difficulties in students. For example, perceived loneliness is known to have increased among students ( $\mathrm{Bu}$ et al., 2020; Meda et al., 
medRxiv preprint doi: https://doi.org/10.1101/2021.07.29.21261196; this version posted July 31, 2021. The copyright holder for this preprint (which was not certified by peer review) is the author/funder, who has granted medRxiv a license to display the preprint in perpetuity.

It is made available under a CC-BY-NC-ND 4.0 International license .

2021) and has been shown in previous, non-pandemic, research to be associated with an increased risk of mental health difficulties. (Leigh-Hunt et al., 2017)

Thus, we report here on the mental wellbeing in a UK university student cohort over 3 periods during university term 2020-2021, with a view to examining the persistence of mental health difficulties, and the demographic and psychological predictors of changes in anxiety and depression over time.

\section{Materials and Methods}

\section{Recruitment}

Ethical approval was received from the University of Nottingham Faculty of Health Sciences Research Ethics Committee (FMHS 96-0920). Participants were not compensated for their initial participation but were offered $£ 10$ per person for completing two follow-up surveys. Students enrolled at the University of Nottingham aged 18 or above were invited to participate via recruitment emails and through a social media campaign. Recruitment took place between October $5^{\text {th }} 2020$ and November $1^{\text {st }} 2020$.

\section{Procedures}

Participants provided informed consent online before completing the online survey (JISC Online Surveys). The baseline survey was administered between 5/10/2020 - 1/11/2020 (Autumn term 2020-2021, pre second lockdown in England). All participants were invited by email to complete a second survey in February (1/2/2021-26/2/2021, Spring term 2020-2021, post-exam, 4 weeks into the third lockdown in England). Those who completed the second survey were invited to complete a final survey in March (10/3/2021 - 26/3/2021, Spring term 2020-2021, 9 weeks into the third lockdown in England).

At baseline, we collected data on sociodemographic characteristics (age, gender, stage of study, international status, pre-existing physical health issues, previous diagnosis of mental 
medRxiv preprint doi: https://doi.org/10.1101/2021.07.29.21261196; this version posted July 31, 2021. The copyright holder for this preprint (which was not certified by peer review) is the author/funder, who has granted medRxiv a license to display the preprint in perpetuity.

It is made available under a CC-BY-NC-ND 4.0 International license .

health disorders). In February and March we asked participants to report if they had to selfisolate at any point. At all time points we measured mental health outcomes including depression (Patient Health Questionnaire (PHQ-9, baseline $\alpha=0.90$ ), anxiety (Generalized Anxiety Disorder Scale (GAD-7, baseline $\alpha=0.92$ ), and stress (Perceived Stress Scale (PSS4, baseline $\alpha=0.70$ ) and other psychological factors including positive mood (Scale of Positive and Negative Experience-Positive, SPANE-P, baseline $\alpha=0.93)$, loneliness, COVID19 worry for themselves and close others. (Sheldon Cohen, 1988; Diener et al., 2010;

Kroenke et al., 2010; Spitzer et al., 2006) Measures of sociodemographic characteristics, loneliness, positive mood, COVID-19 worry are described in Supplementary Appendix S1. Due to changes in social restriction measures before and after the university winter break, we expected some of the student to be unable to return to the university. Therefore location status was collected both in February and March in three categories: returned home for winter break and have not yet returned to the university, returned home for winter break but have returned to the university, never left the university during winter break.

\section{Statistical analysis}

We first summarised the outcome variables (depression, anxiety and stress scores) and participant characteristics with appropriate descriptive statistics and examined histograms and scatterplots for normality. Depression and anxiety scores were square-root transformed due to non-normal distribution. Comparisons with pre-pandemic normative values were made using independent samples t-tests. (R. D. Kocalevent et al., 2013; B. Löwe et al., 2008) We then carried out analyses dichotomising depression and anxiety scores according to established thresholds for 'caseness' of depression and anxiety (PHQ-9 score greater or equal to 10, GAD-7 score greater or equal to 8). (National Collaborating Centre for Mental Health, 2019) Comparisons of mental health outcomes at three time-points were made using one-way 
medRxiv preprint doi: https://doi.org/10.1101/2021.07.29.21261196; this version posted July 31, 2021. The copyright holder for this preprint (which was not certified by peer review) is the author/funder, who has granted medRxiv a license to display the preprint in perpetuity.

It is made available under a CC-BY-NC-ND 4.0 International license .

repeated measures ANOVA. Cochran's Q tests were conducted to examine the differences in the proportions of depression and anxiety cases over time.

Multivariable linear regression models were used to explore the independent relationships of demographic factors (age, gender, ethnicity, level of study, previous diagnosis of mental health disorders) and baseline psychological factors (perceived loneliness, perceived risk of COVID-19, positive mood, COVID-19 worry), and depression, anxiety and stress scores in February and March separately. Location and experiences of selfisolation by February or March were also controlled for in these models. Assumptions of linear regression (normality and homoscedasticity of residuals, linearity with continuous variables) and presence of outliers were assessed graphically. Incidence of depression or anxiety referred to individuals who were not classified as cases for depression or anxiety at baseline but became cases by February or March. We used logistic regression to estimate odds ratios (ORs) with $95 \%$ confidence intervals for associations with incidence and improvement of depression and anxiety cases by February or March using demographic and psychological factors at baseline, relative to no change of non-cases or cases. Improvement of depression or anxiety referred to individuals who were depression or anxiety cases at baseline but subsequently became non-cases by February or March. Demographic and psychological factors in the previous multivariable linear regression models were also controlled for in the logistic regression analysis.

Statistical analyses were performed using STATA (Version 16) and GraphPad Prism (Version 7).

\section{Results}

\section{Cohort characteristics}


medRxiv preprint doi: https://doi.org/10.1101/2021.07.29.21261196; this version posted July 31, 2021. The copyright holder for this preprint (which was not certified by peer review) is the author/funder, who has granted medRxiv a license to display the preprint in perpetuity.

It is made available under a CC-BY-NC-ND 4.0 International license.

In total, 897 students were recruited. Four participants were excluded due to being < 18 years.

Of these $60 \%(\mathrm{n}=540)$ completed a follow-up survey in February and $53 \%(\mathrm{n}=476)$

completed all three surveys. The final cohort $(\mathrm{n}=476)$ was predominately undergraduate students $(n=420,88 \%)$ with an average age of 20.8 years $(\mathrm{SD}=3.7)$ and $71 \%(\mathrm{n}=335)$ of female participants. Comparisons showed that participants who were lost to follow-up did not significantly differ from the final cohort on any of the sociodemographic and baseline psychological factors, with the exception for baseline anxiety (median (IQR), lost to followup: $3.00(0.00-7.00)$ vs completers: $3.00(1.00-8.00), \mathrm{t}=2.04, p=.042)$.

Table 1: Demographics among the final cohort and lost to follow-ups

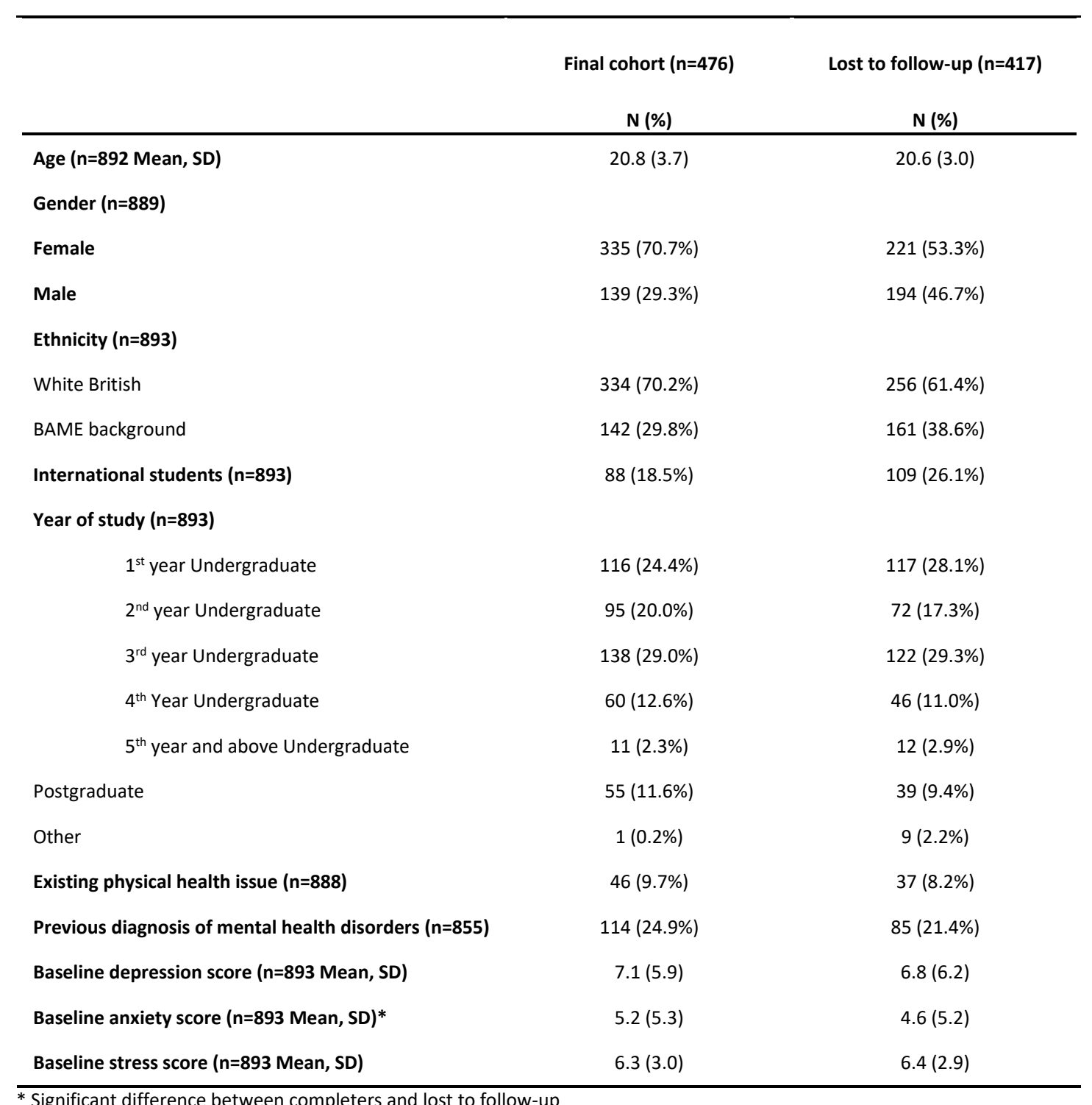


medRxiv preprint doi: https://doi.org/10.1101/2021.07.29.21261196; this version posted July 31, 2021. The copyright holder for this preprint (which was not certified by peer review) is the author/funder, who has granted medRxiv a license to display the preprint in perpetuity.

It is made available under a CC-BY-NC-ND 4.0 International license .

\section{Mental health over time}

Figure 1 shows the means of depression, anxiety, and stress among people who completed all 3 surveys over time. There were differences in means over time for depression $(F(2$, $474)=31.85, p<.001)$, anxiety $(F(2,474)=33.87, p<.001)$, and stress $(F(2,474)=3.70, p=.03)$. Depression and anxiety showed similar patterns: being highest in February compared with baseline (depression: $\mathrm{F}(1,475)=57.01, p<.001$, anxiety: $\mathrm{F}(1,475)=67.73, p<.001)$ and March (depression: $\mathrm{F}(1,475)=20.63, p<.001$; anxiety: $\mathrm{F}(1,475)=6.41, p=.012)$, while levels at baseline were significantly lower than in March (depression: $\mathrm{F}(1,475)=7.56, p=.006$; anxiety: $\mathrm{F}(1,475)=31.53, p<.001)$. For perceived stress, levels were higher in February compared with baseline $(\mathrm{F}(1,475)=6.32, p=.012)$. No significant differences were found between March and either February $(\mathrm{F}(1,475)=19.36, p=.06)$ or baseline $(\mathrm{F}(1,475)=0.72, p=.40)$. Mean values were higher than published population norms among young adults for depression and anxiety (all $p<0.001$ ) at all three time-points but not stress (baseline $p=.13$, February $p=.96$, March $p=.31$ ). (R. D. Kocalevent et al., 2013; B. Löwe et al., 2008)

When the scores were categorised into cases where thresholds for high-intensity psychological support in the NHS were met (i.e., score of 10 or greater for depression, and 8 or greater for anxiety), (National Collaborating Centre for Mental Health, 2019) results showed similar patterns. The prevalence of depression cases was lowest at baseline (29\%), compared with February (37\%, Cochran's Q=18.29, $p<.001)$ and March (33\%, Cochran's $\mathrm{Q}=4.05, p=.04)$, but no difference was observed between February and March (Cochran's $\mathrm{Q}=3.31, p=.07)$. The prevalence of anxiety cases was lowest at baseline (22\%), compared with in February (32\%, Cochran's $\mathrm{Q}=28.96, p<.001)$ and March $(28 \%$, Cochran's $\mathrm{Q}=6.72$, $p=.01$ ). The difference between February and March was also significant (Cochran's $\mathrm{Q}=5.69$, $p=.02)$. 


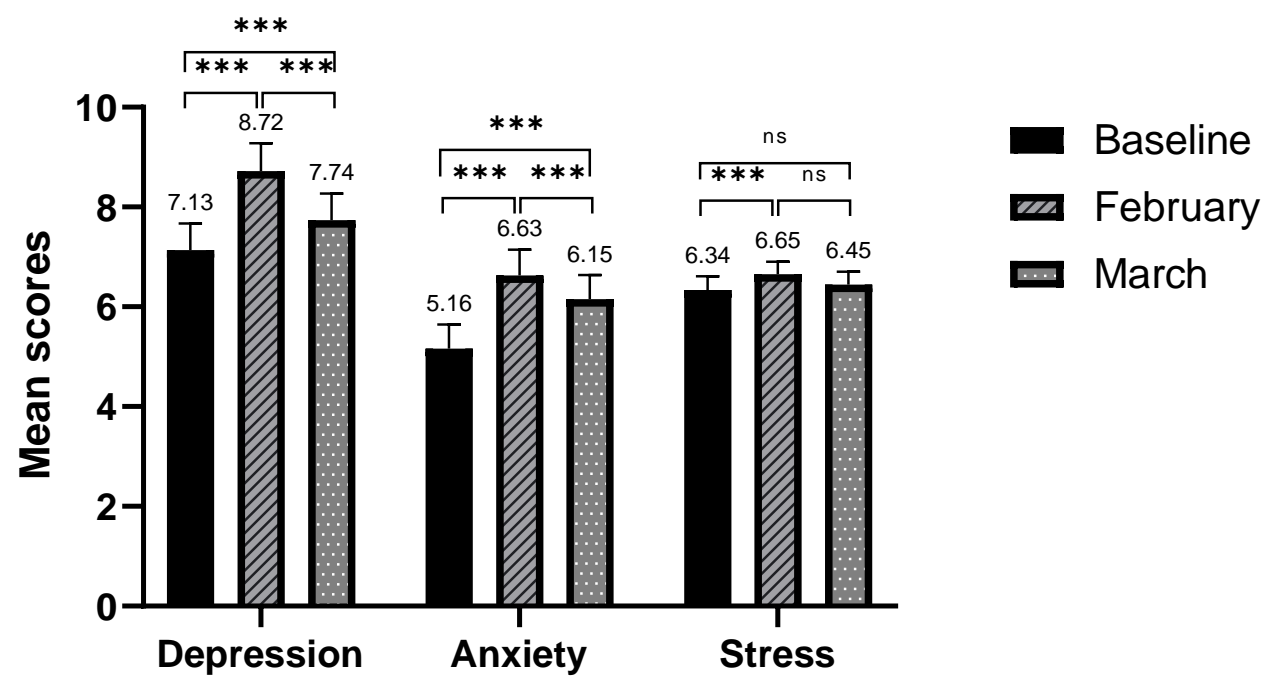

Figure 1. Mean scores for depression, anxiety, and stress over time among the final cohort $(n=476)$. Bars are mean scores. Error bars are $95 \%$ confidence intervals. Score ranges: depression (0-27), anxiety (0-21), stress (0-16). Significant levels were based on repeated measure one-way ANOVA (square-root transformed mean scores for depression and anxiety, ${ }^{* * *} p<.001$ ).

\section{Predictors of mental health outcomes}

Positive mood, loneliness, and COVID-19 worry over time

Figure 2 shows the mean scores for positive mood, loneliness, and COVID-19 worry (for self and close others) at all three time-points. ANOVA analyses showed a statistically significant main effect for time on all psychological measures (positive mood: $F(2,474)=15.40, p<.001$; loneliness: $F(2,474)=11.98, p<.001$; COVID-19 worry for self: $F(2,474)=57.65, p<.001$; COVID-19 worry for close others: $F(2,474)=48.44, p<.001)$. Post hoc testing revealed that mean scores for positive mood and loneliness in February were significantly different to baseline (positive mood: 20.11 vs $21.05, p<.001$, loneliness: 2.15 vs $1.94, p<.001$ ) and in March (positive mood: 20.11 vs 20.94, $p<.001$, loneliness: 2.15 vs 1.92, $p<.001$ ). However, the differences between baseline and March for both positive mood (21.05 vs 20.94, $p=.58$ ) and loneliness were non-significant (1.94 vs 1.92, $p=.83$ ). Mean scores for COVID-19 worry 
medRxiv preprint doi: https://doi.org/10.1101/2021.07.29.21261196; this version posted July 31, 2021. The copyright holder for this preprint (which was not certified by peer review) is the author/funder, who has granted medRxiv a license to display the preprint in perpetuity.

It is made available under a CC-BY-NC-ND 4.0 International license .

for both self (baseline: 1.97, February: 1.77, March: 1.62) and close others (baseline: 2.34, February: 2.21, March: 2.03) were significantly different between each two time-points (all $p<.001)$.

\section{Predicting spring term depression}

Multivariable prospective regression analyses were conducted to explore sociodemographic and psychological predictors of mental health outcomes (Table 2). For depression, having previous diagnosis of a mental health disorder (February: $\mathrm{B}=0.43, \mathrm{CI}$ : 0.22, 0.65; March: $\mathrm{B}=0.45$, CI: $0.22,0.69$ ), lower positive mood at baseline (February: $\mathrm{B}=-0.10, \mathrm{CI}:-0.12,-0.07$; March: $\mathrm{B}=-0.09 \mathrm{CI}:-0.12,-0.07$ ) and greater loneliness at baseline (February: $\mathrm{B}=0.14, \mathrm{CI}$ : 0.06, 0.22; March: $\mathrm{B}=0.15$, CI: 0.06, 0.24) were significantly and independently associated with increased levels of depression in both February and March. Being female (B=0.29, CI: $0.09,0.48)$ and staying at the university during the winter break $(B=0.47, \mathrm{CI}: 0.18,0.75)$ were the only variables to be significantly associated with greater depression in February.

\section{Predicting spring term anxiety}

For anxiety, being female (February: $B=0.46, C I: 0.25,0.68$; March: $B=0.29$, CI: 0.06, 0.51), having a previous diagnosis of mental health disorders (February: $\mathrm{B}=0.49, \mathrm{CI}$ : $0.25,0.73$; March: B=0.56, CI: 0.32, 0.81), lower positive mood at baseline (February: B=-0.09, CI: $0.12,-0.07$; March: B=-0.09, CI: -0.11, -0.06) were significantly and independently associated with greater anxiety in both February and March. Greater loneliness at baseline $(B=0.14, C I: 0.05,0.23)$ and greater COVID-19 worry $(B=0.21, C I: 0.07,0.36)$ were significantly associated with greater anxiety in February.

\section{Predicting spring term stress}

For stress, having a previous diagnosis of mental health disorders (February: $\mathrm{B}=1.09, \mathrm{CI}$ : .54, 1.64; March: $\mathrm{B}=0.93$, CI: 0.0.35, 1.51), lower positive mood at baseline (February: $\mathrm{B}=-0.22$, CI: $-0.27,-0.17$; March: $\mathrm{B}=-0.22 \mathrm{CI}:-0.28,-0.17)$ and greater COVID-19 worry at baseline 
medRxiv preprint doi: https://doi.org/10.1101/2021.07.29.21261196; this version posted July 31, 2021. The copyright holder for this preprint (which was not certified by peer review) is the author/funder, who has granted medRxiv a license to display the preprint in perpetuity.

It is made available under a CC-BY-NC-ND 4.0 International license .

(February: $\mathrm{B}=0.40$, CI: 0.07, 0.73; March: $\mathrm{B}=0.42$, CI: 0.07, 0.76) were significantly and independently associated with greater stress in both February and March. Being female $(B=0.84, C I: 0.34,1.34)$ and staying at the university during the winter break $(B=0.75, C I$ : $0.03,1.48)$ were significantly associated with greater stress in February, while being younger $(B=-0.08, C I:-0.16,-0.01)$ and from BAME background (B=0.63, CI: 0.11, 1.15) were significantly associated with greater stress in March.

\section{Predictors of incident or improved depression and anxiety cases}

We then explored risk factors predicting who became a case of depression or anxiety during the spring term, and those who became a non-case during this time (Table 3). Having previous diagnosis of mental health disorders (OR=2.45, 95\% CI: 1.27, 4.70,), lower baseline positive mood $(\mathrm{OR}=0.90,95 \% \mathrm{CI}: 0.84,0.97)$, and greater baseline loneliness $(\mathrm{OR}=1.32$, 95\% CI: 1.03, 1.69) were risk factors of incidence of depression cases, compared with those who were non-cases at all three time points. The results were slightly different for incidence of cases of anxiety: only female gender (OR=2.04, 95\% CI: 1.14, 3.65) and lower baseline positive mood $(\mathrm{OR}=0.88,95 \% \mathrm{CI}: 0.83,0.94)$ were independent risk factors. When looking at improved depression or anxiety cases, greater positive mood at baseline was a significant predictor for both depression and anxiety (depression: $\mathrm{OR}=1.11,95 \% \mathrm{CI}$ : $1.02,1.22$; anxiety: $\mathrm{OR}=1.15,95 \% \mathrm{CI}: 1.04,1.28)$, compared with those who stayed cases at all time points. No previous diagnosis of mental health disorders was also a significant predictor of improved anxiety cases $(\mathrm{OR}=0.44,95 \% \mathrm{CI}: 0.20,0.96)$. 
Positive mood

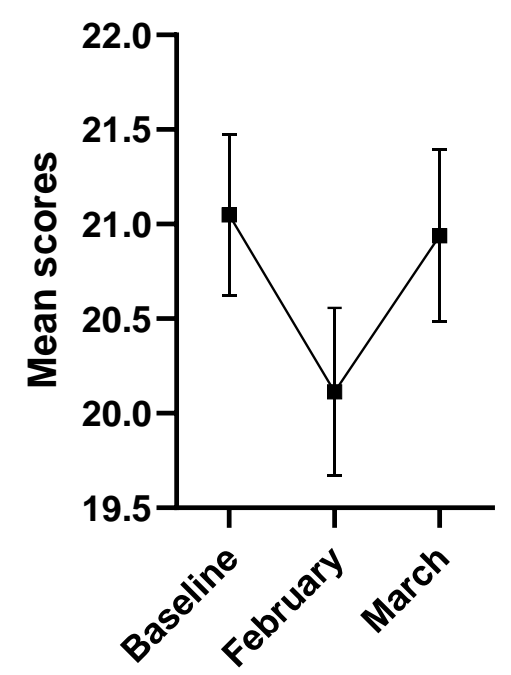

Loneliness

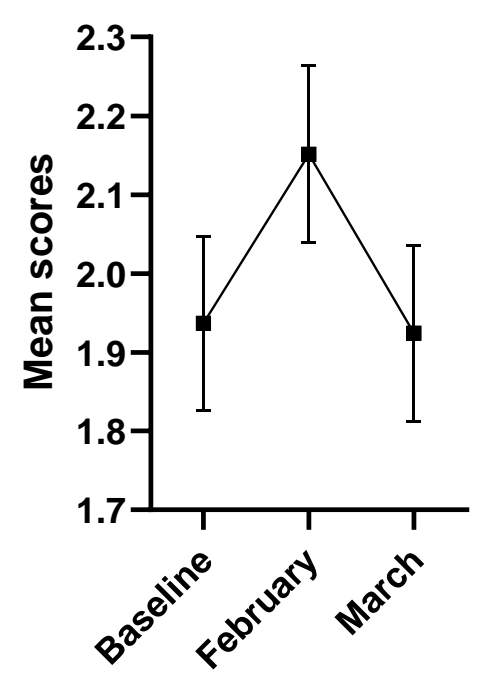

Covid-19 worry



- For self

$\leftarrow$ For close others

Figure 2. Mean scores for positive mood, loneliness, and COVID-19 worry (for self and others) over time among the final cohort ( $\mathrm{n}=476$ ). Bars are mean scores. Error bars are $95 \%$ confidence intervals. The mean scores for positive mood and loneliness in February were significantly different to baseline and March ( $p<0.001)$. The differences between mean scores at baseline and in March for positive mood and loneliness were non-significant ( $p>05)$. Mean scores for COVID-19 worry for both self and close others were significantly different between each two time-points $(p<.001)$. 
Table 2: Regression models showing prospective associations between sociodemographic and psychological explanatory variables at baseline and depression, anxiety and stress scores in February and March

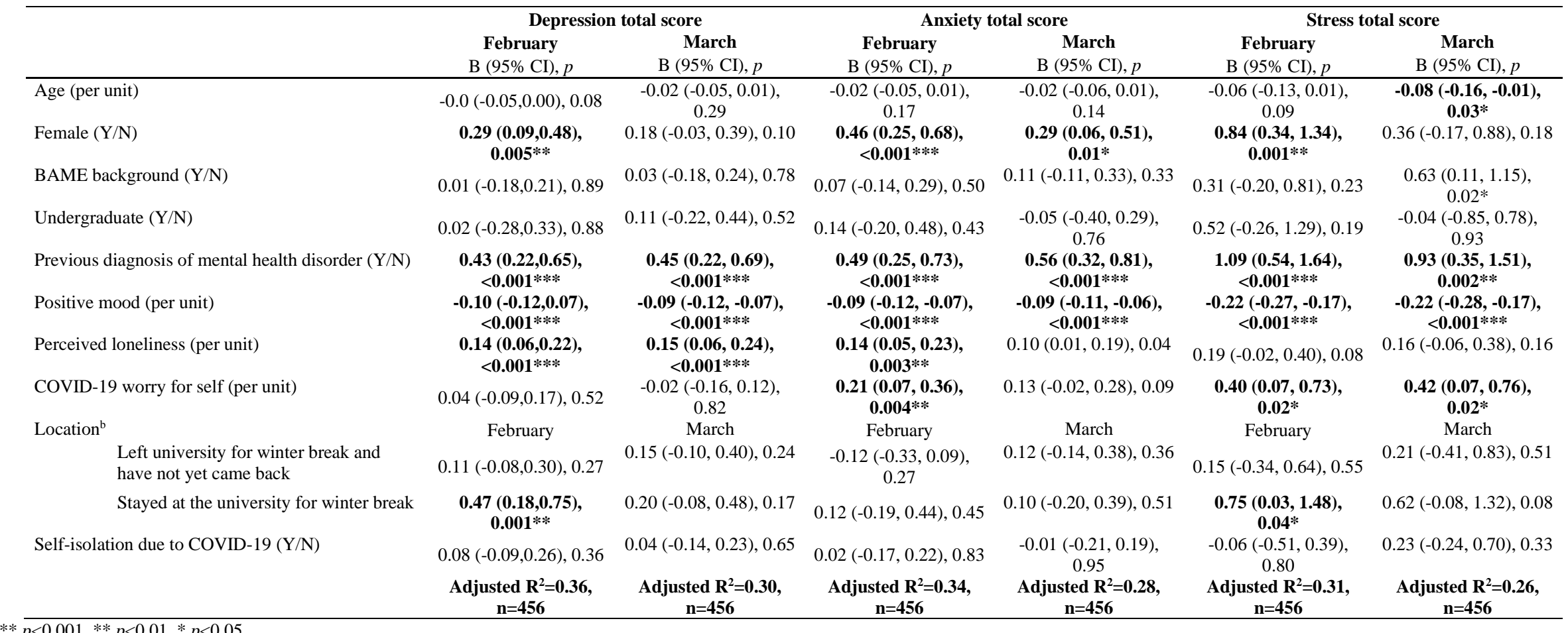

*** $p<0.001, * * p<0.01, * p<0.05$
${ }^{a}$ A square-root transformation was applied to the dependent variable.

"A square-root transformation was applied to the dependent variable.
b Location at time of survey, comparison reference group "I left the university for winter break and have recently returned to the university". 
Table 3: Logistic regression models showing associations between explanatory variables and incidence and prognosis of depression and anxiety cases ${ }^{\text {a }}$

\begin{tabular}{|c|c|c|c|c|}
\hline & $\begin{array}{c}\text { Incident depression cases } \\
\text { 'bdds Ratio }(95 \% \text { CI }), p\end{array}$ & $\begin{array}{l}\text { Incident anxiety cases b }^{\text {b }} \\
\text { Odds Ratio }(95 \% \mathrm{CI}), p\end{array}$ & $\begin{array}{c}\text { Improved depression cases } \\
\text { Odds Ratio }(95 \% \text { CI }), p\end{array}$ & $\begin{array}{c}\text { Improved anxiety cases } \\
\text { odds Ratio }(95 \% \mathrm{CI}), p\end{array}$ \\
\hline$\overline{\text { Age (per unit) }}$ & $0.97(0.89,1.05), 0.43$ & $0.97(0.90,1.05), 0.48$ & $0.96(0.84,1.08), 0.49$ & $1.07(0.92,1.26), 0.37$ \\
\hline Female $(\mathrm{Y} / \mathrm{N})$ & $1.66(0.94,2.92), 0.08$ & $2.04(1.14,3.65), 0.02 *$ & $0.92(0.40,2.09), 0.84$ & $0.59(0.22,1.63), 0.31$ \\
\hline BAME background $(\mathrm{Y} / \mathrm{N})$ & $0.86(0.49,1.51), 0.59$ & $1.16(0.67,1.99), 0.60$ & $0.83(0.41,1.69), 0.62$ & $0.75(0.33,1.71), 0.50$ \\
\hline Undergraduate $(\mathrm{Y} / \mathrm{N})$ & $1.32(0.52,3.32), 0.56$ & $0.81(0.34,1.92), 0.64$ & $1.31(0.41,4.18), 0.64$ & $1.16(0.29,4.62), 0.84$ \\
\hline Previous diagnosis of mental health disorder $(\mathrm{Y} / \mathrm{N})$ & $2.45(1.27,4.70), 0.007^{* *}$ & $1.65(0.88,3.11), 0.12$ & $0.51(0.25,1.03), 0.06$ & $0.44(0.20,0.96), 0.04 *$ \\
\hline Positive mood (per unit) & $0.90(0.84,0.97), 0.004 * *$ & $0.88(0.83,0.94),<0.001 * * *$ & $1.11(1.02,1.22), 0.02^{*}$ & $1.15(1.04,1.28), 0.007^{* *}$ \\
\hline Perceived loneliness (per unit) & $1.32(1.03,1.69), 0.03 *$ & $1.11(0.87,1.41), 0.40$ & $0.83(0.61,1.14), 0.25$ & $0.79(0.55,1.13), 0.71$ \\
\hline COVID-19 worry for self (per unit) & $1.07(0.71,1.62), 0.75$ & $1.29(0.86,1.95), 0.22$ & $0.92(0.59,1.42), 0.70$ & $0.91(0.56,1.48), 0.42$ \\
\hline $\mathrm{N}$ & 338 & 365 & 164 & 133 \\
\hline Pseudo $\mathrm{R}^{2}$ & 0.11 & 0.09 & 0.10 & 0.13 \\
\hline
\end{tabular}

**** $p<0.001, * * p<0.01, * p<0.05$

${ }^{a}$ A 'case' is defined as the PHQ-9 score greater or equal to 10 for depression, or the GAD-7 score greater or equal to 8 for anxiety, at which level someone would qualify for high-intensity psychological support in the

National Health Service.

${ }^{\mathrm{b}}$ Incident case refers to those who were not 'cases' at baseline and subsequently became a 'case' by February or March. The comparison groups were non-cases of depression and non-cases of anxiety at all 3 time periods, respectively.

' Improved case refers to those who were 'cases' at baseline and subsequently became 'non-cases' by February or March. The comparison groups were cases of depression and cases of anxiety at all 3 time periods, respectively. 
medRxiv preprint doi: https://doi.org/10.1101/2021.07.29.21261196; this version posted July 31, 2021. The copyright holder for this preprint (which was not certified by peer review) is the author/funder, who has granted medRxiv a license to display the preprint in perpetuity.

It is made available under a CC-BY-NC-ND 4.0 International license .

\section{Discussion}

We report here prospective findings from a longitudinal university student cohort established at the beginning of the 2020-2021 Academic Year in the midst of the COVID-19 pandemic. We observed that the overall levels of depression and anxiety significantly exceeded prepandemic normative data in similarly aged young adults at all time points. Of particular note was the fact that levels of depression, anxiety and stress all worsened in February 2021. It is possible that these increases in mental health difficulties were partly due to the strict and protracted lockdown measures since early January when most universities were delivering education virtually and students were unable to meet others outside their household. Despite the significant improvements by the end of March 2021, levels of depression and anxiety did not return to baseline levels. This suggests that the impact of the social restrictions on students' mental health persisted throughout lockdown. However, it is also possible that students, like the general public, generally experience greater mental health difficulties in the winter when low mood and depressive symptoms are more prevalent. (Yang et al., 2010) Whether the increase in the mental health difficulties were mainly due to the lockdown restrictions or seasonal (Yang et al., 2010), our data showed concerning levels of mental health difficulties especially depression and anxiety in students. Universities should be aware of these difficulties and the likely increase in the demand for counselling services. Delivering adequate and timely psychological support to those in need is crucial. (Galea et al., 2020) Continued monitoring of students' mental health may also be advantageous as students and the public traverse the next stages of the pandemic including the potential for a resumption of some restrictions in the winter months.

Another crucial element of dealing with the mental health difficulties is to identify who is at greater risk. In terms of demographic characteristics, we found that female gender was significantly associated with greater depression, anxiety and stress in February and 
medRxiv preprint doi: https://doi.org/10.1101/2021.07.29.21261196; this version posted July 31, 2021. The copyright holder for this preprint (which was not certified by peer review) is the author/funder, who has granted medRxiv a license to display the preprint in perpetuity.

It is made available under a CC-BY-NC-ND 4.0 International license .

anxiety in March. This echoes evidence from other cohorts in the pandemic and earlier evidence that seasonal depressive symptoms are more prevalent in women. (Elmer et al., 2020; Fancourt et al., 2021; Lyall et al., 2018) Having a previous diagnosis of mental health disorders was also a significant risk factor for depression, anxiety, and stress at follow-ups, which has also been identified as a risk factor in other cohorts. (Fancourt et al., 2021) Female students in our cohort also had double the odds of becoming an anxiety case, and having a previous diagnosis of a mental health disorder almost tripled the odds of becoming a depression case during follow-up, compared with those who remained non-cases. The consistency in these findings, both in our study and other cohorts (ONS) Jia, et al., 2020; ONS), suggests that individuals with these two characteristics are most vulnerable to future mental health difficulties. Universities are recommended to promote education or campaigns to raise awareness of mental well-being, especially in these groups. Interestingly, we also observed that students who stayed at the university during the winter break (or university closure period) were at increased risk of reporting greater depression and stress in February compared with those who went home and returned later. It is possible that these students were separated from their regular social interactions during and after the winter break partly due to lockdown measures, hence were lacking psychosocial resources to cope with potential mental health difficulties. This is also reflected by the increased loneliness and reduced positive mood in February in our results. It is important to note that, in a post-pandemic future, a proportion of students might still stay on campus during university closure periods. Although more evidence is needed, universities should be aware that these students might be at higher risks of mental health difficulties during this time therefore support should be made available especially in the winter months.

In terms of psychological risk factors, after taking demographic factors into account, we observed that lower positive mood at baseline was associated with depression, anxiety, 
medRxiv preprint doi: https://doi.org/10.1101/2021.07.29.21261196; this version posted July 31, 2021. The copyright holder for this preprint (which was not certified by peer review) is the author/funder, who has granted medRxiv a license to display the preprint in perpetuity.

It is made available under a CC-BY-NC-ND 4.0 International license .

and stress while greater baseline loneliness was associated with depression in both February and March, explaining 26-36\% of the variance, in addition to the effect of other variables. These results were in line with other evidence at early stages of the pandemic. (Elmer et al., 2020; Jia, Ayling, Chalder, Massey, Broadbent, Coupland, et al., 2020; Meda et al., 2021) Students with lower positive mood or greater loneliness at baseline also had greater odds of developing depression in February and March, compared with those who were not cases at any timepoint. These results firstly echo risk factors identified by other studies (e.g., low social contact and emotional support) associated with negative mental health trajectories in students and the general population. (Elmer et al., 2020; Fancourt et al., 2021) Secondly, they suggest that loneliness and positive mood might mitigate the mental health sequela of COVID-19. Our analysis further showed that greater baseline positive mood was the only common predictor of improved cases of depression and anxiety during follow-up, compared with those who stayed cases at all time points. Taken together, it is suggested that positive mood might not only contribute to depression and anxiety, but might also act as a protective factor against deteriorations of mental health over time. (S. Cohen et al., 2003) Evidence has shown the effectiveness of positive psychology interventions (e.g., mindfulness and positive writing) in improving well-being and decreasing depressive symptoms among young people. (Sin \& Lyubomirsky, 2009) Technology-based psychological interventions (e.g., digital mood-monitoring tools and virtual reality), as well as other interventions such as physical activity and animal interactions might also be effective in this group. (Barton \& Pretty, 2010; Dubad et al., 2018; Grajfoner et al., 2017; Habak et al., 2020)

\section{Limitations}

Despite the several strengths of this study such as longitudinal design and relatively large cohort, we acknowledge several limitations. First, the observational nature of the study means we cannot assume causal relationships between mental health outcomes and the impact of the 
medRxiv preprint doi: https://doi.org/10.1101/2021.07.29.21261196; this version posted July 31, 2021. The copyright holder for this preprint (which was not certified by peer review) is the author/funder, who has granted medRxiv a license to display the preprint in perpetuity. It is made available under a CC-BY-NC-ND 4.0 International license .

COVID-19 pandemic. Second, nearly half (47\%) of the original cohort were lost to followup. Although those who were lost to follow-up and completed all three surveys did not differ on most of the sociodemographic and baseline mental health measures, with the exception of anxiety. Although unlikely, it is possible that by excluding right censored data, our results overrepresented those with higher baseline anxiety. Third, our participants were self-selected and from a single institution in England with predominant proportion of undergraduate students and higher proportion of women than reported by Higher Education Policy Institute, (Higher Education Policy Institute) which also limits the generalisability of our findings. Nevertheless, our study showed the profound mental health difficulties university students experienced during the COVID-19 pandemic and point to potential avenues for psychological intervention (i.e., interventions addressing loneliness and positive mood).

\section{Acknowledgements}

We would like to thank all our participants as well as individuals and groups who provided help during our recruitment. 
medRxiv preprint doi: https://doi.org/10.1101/2021.07.29.21261196; this version posted July 31, 2021. The copyright holder for this preprint (which was not certified by peer review) is the author/funder, who has granted medRxiv a license to display the preprint in perpetuity.

It is made available under a CC-BY-NC-ND 4.0 International license .

\section{References}

Barton, J., \& Pretty, J. (2010). What is the best dose of nature and green exercise for improving mental health? A multi-study analysis. Environ Sci Technol, 44(10), 39473955. https://doi.org/10.1021/es903183r

Bu, F., Steptoe, A., \& Fancourt, D. (2020). Who is lonely in lockdown? Cross-cohort analyses of predictors of loneliness before and during the COVID-19 pandemic. Public Health, 186, 31-34. https://doi.org/10.1016/j.puhe.2020.06.036

Cohen, S. (1988). Perceived stress in a probability sample of the United States (The social psychology of health. (pp. 31-67). Sage Publications, Inc.

Cohen, S., Doyle, W. J., Turner, R. B., Alper, C. M., \& Skoner, D. P. (2003). Emotional style and susceptibility to the common cold. Psychosom Med, 65(4), 652-657. https://doi.org/10.1097/01.psy.0000077508.57784.da

Diener, E., Wirtz, D., Tov, W., Kim-prieto, C., Choi, D.-w., Oishi, S., \& Biswas-Diener, R. (2010). New Well-being Measures: Short Scales to Assess Flourishing and Positive and Negative Feelings. Social Indicators Research, 97, 143-156.

Dubad, M., Winsper, C., Meyer, C., Livanou, M., \& Marwaha, S. (2018). A systematic review of the psychometric properties, usability and clinical impacts of mobile moodmonitoring applications in young people. Psychol Med, 48(2), 208-228. https://doi.org/10.1017/s0033291717001659

Elmer, T., Mepham, K., \& Stadtfeld, C. (2020). Students under lockdown: Comparisons of students' social networks and mental health before and during the COVID-19 crisis in Switzerland. PloS one, 15(7), e0236337. https://doi.org/10.1371/journal.pone.0236337

Fancourt, D., Steptoe, A., \& Bu, F. (2021). Trajectories of anxiety and depressive symptoms during enforced isolation due to COVID-19 in England: a longitudinal observational study. The Lancet Psychiatry, 8(2), 141-149. https://doi.org/10.1016/S22150366(20)30482-X

Folkman, S., Chesney, M., McKusick, L., Ironson, G., Johnson, D. S., \& Coates, T. J. (1991). Translating Coping Theory into an Intervention. In J. Eckenrode (Ed.), The Social Context of Coping (pp. 239-260). Springer US. https://doi.org/10.1007/978-1-48993740-7_11

Galea, S., Merchant, R. M., \& Lurie, N. (2020). The Mental Health Consequences of COVID-19 and Physical Distancing: The Need for Prevention and Early Intervention. JAMA Intern Med, 180(6), 817-818. https://doi.org/10.1001/jamainternmed.2020.1562

Grajfoner, D., Harte, E., Potter, L. M., \& McGuigan, N. (2017). The Effect of Dog-Assisted Intervention on Student Well-Being, Mood, and Anxiety. International journal of environmental research and public health, 14(5). https://doi.org/10.3390/ijerph14050483

Habak, S., Bennett, J., Davies, A., Davies, M., Christensen, H., \& Boydell, K. M. (2020). Edge of the Present: A Virtual Reality Tool to Cultivate Future Thinking, Positive Mood and Wellbeing. International journal of environmental research and public health, 18(1). https://doi.org/10.3390/ijerph18010140

Higher Education Policy Institute. https://www.hepi.ac.uk/2020/03/07/mind-the-gap-genderdifferences-in-higher-education/ [Accessed 28/06/2021].

Jia, R., Ayling, K., Chalder, T., Massey, A., Broadbent, E., Coupland, C., \& Vedhara, K. (2020). Mental health in the UK during the COVID-19 pandemic: cross-sectional analyses from a community cohort study. BMJ Open, 10(9), e040620.

https://doi.org/10.1136/bmjopen-2020-040620 
medRxiv preprint doi: https://doi.org/10.1101/2021.07.29.21261196; this version posted July 31, 2021. The copyright holder for this preprint (which was not certified by peer review) is the author/funder, who has granted medRxiv a license to display the preprint in perpetuity.

It is made available under a CC-BY-NC-ND 4.0 International license .

Jia, R., Ayling, K., Chalder, T., Massey, A., Broadbent, E., Morling, J. R., Coupland, C., \& Vedhara, K. (2020). Young people, mental health and COVID-19 infection: the canaries we put in the coal mine. Public Health, 189, 158-161. https://doi.org/https://doi.org/10.1016/j.puhe.2020.10.018

Jia, R., Knight, H., Blake, H., Corner, D. J., Denning, C., Ball, J., Bolton, K., Morling, J. R., Coupland, C., Figueredo, G., Morris, D. E., Tighe, P., Villalon, A., Ayling, K., \& Vedhara, K. (2020). Experiences of the COVID-19 pandemic: cross-sectional analysis of risk perceptions and mental health in a student cohort. medRxiv, 2020.2012.2021.20248467. https://doi.org/10.1101/2020.12.21.20248467

Kocalevent, R.-D., Hinz, A., \& Brähler, E. (2013). Standardization of the depression screener Patient Health Questionnaire (PHQ-9) in the general population. General Hospital Psychiatry, 35(5), 551-555. https://doi.org/https://doi.org/10.1016/j.genhosppsych.2013.04.006

Kocalevent, R. D., Hinz, A., \& Brähler, E. (2013). Standardization of the depression screener patient health questionnaire (PHQ-9) in the general population. Gen Hosp Psychiatry, 35(5), 551-555. https://doi.org/10.1016/j.genhosppsych.2013.04.006

Kroenke, K., Spitzer, R. L., Williams, J. B., \& Löwe, B. (2010). The Patient Health Questionnaire Somatic, Anxiety, and Depressive Symptom Scales: a systematic review. Gen Hosp Psychiatry, 32(4), 345-359.

https://doi.org/10.1016/j.genhosppsych.2010.03.006

Leigh-Hunt, N., Bagguley, D., Bash, K., Turner, V., Turnbull, S., Valtorta, N., \& Caan, W. (2017). An overview of systematic reviews on the public health consequences of social isolation and loneliness. Public Health, 152, 157-171. https://doi.org/10.1016/j.puhe.2017.07.035

Löwe, B., Decker, O., Müller, S., Brähler, E., Schellberg, D., Herzog, W., \& Herzberg, P. Y. (2008). Validation and standardization of the Generalized Anxiety Disorder Screener (GAD-7) in the general population. Med Care, 46(3), 266-274. https://doi.org/10.1097/MLR.0b013e318160d093

Löwe, B., Decker, O., Müller, S., Brähler, E., Schellberg, D., Herzog, W., \& Herzberg, P. Y. (2008). Validation and Standardization of the Generalized Anxiety Disorder Screener (GAD-7) in the General Population. Medical Care, 46(3), 266-274. http://www.jstor.org/stable/40221654

Lyall, L. M., Wyse, C. A., Celis-Morales, C. A., Lyall, D. M., Cullen, B., Mackay, D., Ward, J., Graham, N., Strawbridge, R. J., Gill, J. M. R., Ferguson, A., Bailey, M. E. S., Pell, J. P., Curtis, A. M., \& Smith, D. J. (2018). Seasonality of depressive symptoms in women but not in men: A cross-sectional study in the UK Biobank cohort. $J$ Affect Disord, 229, 296-305. https://doi.org/10.1016/j.jad.2017.12.106

Meda, N., Pardini, S., Slongo, I., Bodini, L., Zordan, M. A., Rigobello, P., Visioli, F., \& Novara, C. (2021). Students' mental health problems before, during, and after COVID-19 lockdown in Italy. J Psychiatr Res, 134, 69-77.

https://doi.org/10.1016/j.jpsychires.2020.12.045

National Collaborating Centre for Mental Health. (2019). The Improving Access to Psychological Therapies Manual - Appendices and helpful resources (

Odriozola-González, P., Planchuelo-Gómez, Á., Irurtia, M. J., \& de Luis-García, R. (2020). Psychological effects of the COVID-19 outbreak and lockdown among students and workers of a Spanish university. Psychiatry Res, 290, 113108.

https://doi.org/10.1016/j.psychres.2020.113108

ONS.

https://www.ons.gov.uk/peoplepopulationandcommunity/healthandsocialcare/mentalh 
medRxiv preprint doi: https://doi.org/10.1101/2021.07.29.21261196; this version posted July 31, 2021. The copyright holder for this preprint (which was not certified by peer review) is the author/funder, who has granted medRxiv a license to display the preprint in perpetuity. It is made available under a CC-BY-NC-ND 4.0 International license.

ealth/bulletins/coronavirusandgpdiagnoseddepressioninengland2020/coronavirusandg pdiagnoseddepressioninengland2020 [Accessed 08/06/2021].

Shanahan, L., Steinhoff, A., Bechtiger, L., Murray, A. L., Nivette, A., Hepp, U., Ribeaud, D., \& Eisner, M. (2020). Emotional distress in young adults during the COVID-19 pandemic: evidence of risk and resilience from a longitudinal cohort study. Psychol Med, 1-10. https://doi.org/10.1017/s003329172000241x

Sin, N. L., \& Lyubomirsky, S. (2009). Enhancing well-being and alleviating depressive symptoms with positive psychology interventions: a practice-friendly meta-analysis. $J$ Clin Psychol, 65(5), 467-487. https://doi.org/10.1002/jclp.20593

Spitzer, R. L., Kroenke, K., Williams, J. B., \& Löwe, B. (2006). A brief measure for assessing generalized anxiety disorder: the GAD-7. Arch Intern Med, 166(10), 10921097. https://doi.org/10.1001/archinte.166.10.1092

Xiong, J., Lipsitz, O., Nasri, F., Lui, L. M. W., Gill, H., Phan, L., Chen-Li, D., Iacobucci, M., Ho, R., Majeed, A., \& McIntyre, R. S. (2020). Impact of COVID-19 pandemic on mental health in the general population: A systematic review. J Affect Disord, 277, 55-64. https://doi.org/10.1016/j.jad.2020.08.001

Yang, A. C., Huang, N. E., Peng, C. K., \& Tsai, S. J. (2010). Do seasons have an influence on the incidence of depression? The use of an internet search engine query data as a proxy of human affect. PloS one, 5(10), e13728.

https://doi.org/10.1371/journal.pone.0013728 